\title{
ALGEMEENE VERGADERING
}

\author{
DER \\ LEDEN VAN HET INSTITUUT, \\ GeHouden te 'S gravenhage, 26 maART 1866.
}

\begin{abstract}
$\Leftrightarrow$
De Voorzitter, Jhr. Cornets de Groot van Kraaijenburg, opent op het beschreven uur de vergadering.

De notulen der vorige. algemeene vergadering worden gelezen en goedgekeurd.
\end{abstract}

De Secretaris doet voorlezing van het verslag van den staat en de werkzaamheden van het Instituut over $1865^{1}$.

De Voorzitter benoemt eene commissie tot het opnemen der rekening en verantwoording van den penningmeester over primo Mei tot ultimo December 1866. Op voorstel dier commissie, die de rekening in goede orde heeft bevonden, wordt deze door de vergadering goedgekeurd.

De vergadering betuigt haren dank aan den Secretaris en den Penningmeester voor de door hen volbrachte taak?

Overgaande tot het verkiezen van Bestuursleden, ter vervanging van de heeren Cornets de Groot van Kraaijenburg, Wintgens en van der Wijck, aan wie de beurt van aftreding is en ter vervanging van den heer Roorda, die zijn ontslag heeft genomen, worden met meerderheid van stémmen tot leden van het bestuur gekozen: in de plaats der drie eerstgenoemden, de heeren dr. P. Bleeker, J. M. Obreen en A. W. Egter van Wissekerke en in de plaats van den heer Roorda, aftredende in 1868 , de hẻer dr. G. K. Niemann.

De nieuw gekozen Bestuursleden verklaren de hun opgedragen betrekking aan te nemen, waarop de vergadering, daar niets verder aan de orde is en ook niemand iets in het midden heeft te brengen, door den Voorzitter wordt gesloten.

1 Dit verslag is opgenomen op bladz. $365-378$ der Bijdragen, 3e volgreeks, 1e deel. 